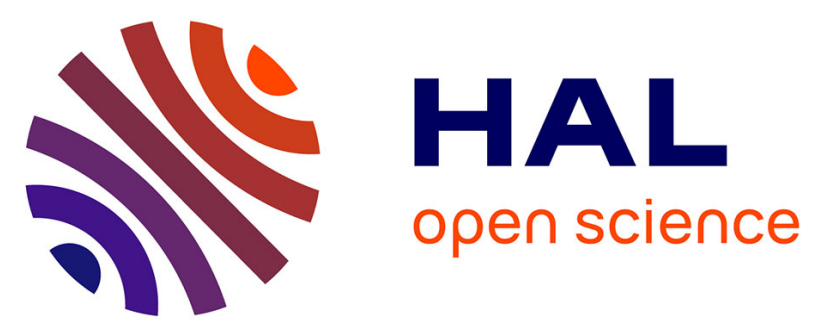

\title{
Effect of digestible carbohydrates on protein/energy utilization and on glucose metabolism in rainbow trout (Salmo gairdneri R.)
}

Sadasivam S. Kaushik, Françoise Médale, Benoit Fauconneau, D. Blanc

\section{To cite this version:}

Sadasivam S. Kaushik, Françoise Médale, Benoit Fauconneau, D. Blanc. Effect of digestible carbohydrates on protein/energy utilization and on glucose metabolism in rainbow trout (Salmo gairdneri R.). Aquaculture, 1989, 79 (1-4), pp.63-74. 10.1016/0044-8486(89)90446-8 . hal-02728074

\section{HAL Id: hal-02728074 \\ https://hal.inrae.fr/hal-02728074}

Submitted on 2 Jun 2020

HAL is a multi-disciplinary open access archive for the deposit and dissemination of scientific research documents, whether they are published or not. The documents may come from teaching and research institutions in France or abroad, or from public or private research centers.
L'archive ouverte pluridisciplinaire HAL, est destinée au dépôt et à la diffusion de documents scientifiques de niveau recherche, publiés ou non, émanant des établissements d'enseignement et de recherche français ou étrangers, des laboratoires publics ou privés. 


\title{
Effect of Digestible Carbohydrates on Protein/ Energy Utilization and on Glucose Metabolism in Rainbow Trout (Salmo gairdneri R.)
}

\author{
S.J. KAUSHIK, F. MEDALE, B. FAUCONNEAU and D. BLANC \\ Laboratoire de Nutrition des Poissons, I.N.R.A., 64310 Saint Pée-sur-Nivelle (France)
}

\begin{abstract}
Kaushik, S.J., Medale, F., Fauconneau, B. and Blanc, D., 1989. Effect of digestible carbohydrates on protein/energy utilization and on glucose metabolism in rainbow trout (Salmo gairdneri R.). Aquaculture, 79: 63-74.
\end{abstract}

Duplicate groups of rainbow trout were fed low-protein (38\%) diets containing high levels (38\%) of five different carbohydrate sources (raw starch, extruded corn, extruded wheat, extruded corn starch or extruded wheat starch ). A modified pair-feeding method was used to allow equal intakes of protein and of digestible energy by each group of fish. Growth parameters were followed over a period of 18 weeks; the digestibility of the diets, nitrogen and energy balances, and the respiratory and ammonia quotients of fish fed the different diets were determined. To study the long-term effects of dietary carbohydrates, plasma glucose profile and its control by bovine insulin was followed in fish fed over 30 weeks with selected test diets. The results show that inclusion of extruded cereals or extruded starch improves availability of dietary energy. High levels of carbohydrates do not adversely affect overall growth or nutrient retention efficiencies. Long-term feeding with carbohydrate-rich diets does not confer on trout any adaptive capacity to regulate postprandial glycemia levels. Respirometric measurements appear to provide interesting data on the metabolic utilization of body substrates.

\section{INTRODUCTION}

In recent years, much work has been devoted to evaluating the protein-sparing effects of energy-yielding nutrients in fish diets. While it is unanimously agreed that addition of fats contributes to such protein-sparing by increasing the digestible energy of the diets (Watanabe et al., 1979; Cho and Kaushik, 1985), some controversy seems to persist as to the beneficial effects of the incorporation of digestible carbohydrates in the diets of carnivorous fish like the salmonids. The poor utilization of dietary carbohydrate sources appears to have both a digestive and a metabolic origin.

As carnivorous fish, salmonids are ill-adapted to digest complex carbohy- 
drates (Inaba et al., 1963; Singh and Nose, 1967) and any physical treatment that might decrease the complexity of the dietary starch appears also to improve its availability to these fish (Luquet and Bergot, 1976; Bergot and Breque, 1983). In a recent work, we showed that incorporation of gelatinized starch in the diets of rainbow trout can lead to an increase in protein and energy retention efficiencies by making available more non-protein digestible energy and also by decreasing the nitrogenous metabolic losses (Kaushik and OlivaTeles, 1985). Watanabe et al. (1987) have also shown similar effects in carp. Rather than using treated starch, it might be more practical to incorporate whole treated cereals in fish feed. Luquet and Bergot (1976) demonstrated the successful utilization of whole corn which had undergone different technological treatments in the feeds of rainbow trout. Besides, when considering the long-term effects of feeding carbohydrate-rich diets, no adaptive regulation of the structure and function of the digestive system seems to operate. On the contrary, the results of Buddington and Hilton (1987) show that both the disaccharidase activities and glucose uptake rates are considerably reduced in trout fed high levels of glucose over a period of 30 weeks.

At the metabolic level, the absorbed glucose also appears to be very poorly utilized by carnivorous fish, as evidenced by prolonged hyperglycemia with insufficient hormonal control of circulating glucose levels (Palmer and Ryman, 1972; Bergot, 1979; Furuichi and Yone, 1981, 1982).

The purpose of the present work is to evaluate different sources of digestible carbohydrates included in trout diets either in the form of extruded starch or in the form of extruded cereals by (1) studying the overall performance and protein and energy utilization efficiencies, (2) evaluating the metabolic utilization of substrates. A further aim was to determine if some metabolic adaptation of glucose homeostasis occurs in trout fed digestible carbohydrates over long periods.

\section{MATERIALS AND METHODS}

\section{Diets}

Five experimental diets were formulated having a common constraint of low protein and high energy levels, the compositions of which are reported in Table 1. Each diet had a different carbohydrate source: raw corn starch (diet RS), extruded corn starch (ECS), extruded wheat starch (EWS), extruded whole corn (EC) or extruded whole wheat (EW). The extrusion processing of cereals and the respective starches was done by Laboratoire de Technologie des Aliments des Animaux (L.T.A.A., I.N.R.A., Nantes, France). The principal protein source was from a high quality fish meal (Norseamink, obtained through Rousselow, France; courtesy of T. Storebakken, Norway). In order to have a more or less similar DE (digestible energy) level in all diets, the fat content of 
TABLE 1

Composition of experimental diets

\begin{tabular}{lccccc}
\hline & RS & ECS & EC & EWS & EW \\
\hline Fishmeal (Norseamink) & 40 & 40 & 40 & 38 & 38 \\
Wheat gluten & - & - & - & 7 & - \\
Corn gluten & 7 & 7 & - & - & - \\
Extruded corn & - & - & 40 & - & - \\
Extruded wheat & - & - & - & - & 38 \\
Extruded corn starch & - & 38 & - & - & - \\
Extruded wheat starch & - & - & - & 38 & - \\
Crude starch (corn) & 37 & - & - & - & - \\
Fish oil & 12 & 3 & 3 & 3 & 3 \\
Vitamin mix & 2 & 2 & 2 & 2 & 2 \\
Mineral mix & 1 & 1 & 1 & 1 & 1 \\
Binder & 1 & 1 & 1 & 1 & 1 \\
& 100 & 92 & 87 & 90 & 83 \\
\hline
\end{tabular}

Daily feeding rate for diet RS (=100) was $2 \%$ of initial body weight.

diet $\mathrm{RS}$ was increased. The different ingredients were blended and pressed into dry pellets of $2 \mathrm{~mm}$ diameter (Simon-Heese Press). For digestibility trials, $1 \%$ of chromic oxide was also incorporated before pelleting.

Diets were formulated in such a way as to provide equal absolute amounts of the major nutrients (protein, carbohydrates and energy) per unit body weight to all groups of fish. In order to achieve this, a modified "pair-feeding" method was used. As can be seen from Table 1, rather than making the diets isonitrogenous or isocaloric with the help of additional non-nutrient fillers, the daily feeding rates varied for each diet so as to achieve a theoretical daily allowance of about $6 \mathrm{~g}$ of digestible protein and about $3 \mathrm{~kJ}$ of $\mathrm{DE} / \mathrm{kg} \mathrm{BW}$ per day. Thus, corresponding to diet RS which was fed at a daily ration of $2 \%$ of initial body weight, the feeding rates for the other diets were fixed at $1.83,1.74,1.80$ and $1.66 \%$ of initial body weight for groups fed diets ECS, EC, EWS and EW respectively. On the basis of periodic weighings (every third week), the amount of food distributed was adjusted to take into account the body weight changes. The scheduled amount of feed per batch of fish was weighed daily and distributed to fish in two equal meals ( 9 a.m. and 4 p.m.)

\section{Growth studies}

Ten groups ( 2 replicates $\times 5$ diets) of 150 rainbow trout each (initial bodyweight $28 \pm 0.5 \mathrm{~g}$ ) were constituted. The growth trial was conducted in our experimental fish farm (I.N.R.A., Donzacq) at a constant water temperature of $17.5 \pm 1^{\circ} \mathrm{C}$. Fish were counted and weighed at the beginning, every third 
week and at the end of the growth experiment that lasted 18 weeks. Initial and final samples of ten fish from each group were drawn for dissection and analyses of body composition. At the end of the growth trial, fish from each group were transferred to the laboratory for digestibility and metabolism trials.

\section{Digestibility measurements}

Apparent digestibility coefficients (ADC) of dry matter, of protein and of energy of the five diets were determined with 10 to 15 fish which were well adapted to the diets. Fish were adapted to the digestibility measurement experimental setup comprised of cylindrical tanks with a conical bottom (vol 60 $\mathrm{l}$; flow rate 3 to $4 \mathrm{l} / \mathrm{min}$ ) and feces collection was carried out following procedures described by Choubert et al. (1982). Feces from each fish tank were collected over 7 days and frozen daily. Analyses of chromic oxide, protein and energy in feces were carried out in pooled, freeze-dried samples.

\section{Nitrogen and energy metabolism trials}

Ten fish from each group were maintained in individual tanks in a recirculated, thermoregulated system for monitoring ammonia nitrogen excretion, oxygen uptake and carbon dioxide excretion. Ammonia excretion rates were measured over 24-h cycles following procedures described by Kaushik (1980). Oxygen and carbon dioxide measurements were made every hour in the inlet and outlet waters using respectively an oxygen electrode (Ponselle, France) and an ion-selective electrode (Orion, U.S.A.). For the determination of postprandial metabolic rates, fish were fed the respective diets and the metabolic rates were measured. The fish were then fasted for 5 days and the parameters measured to determine basal metabolic rates.

From the data on oxygen uptake and carbon dioxide excretion, the respiratory quotients (RQ) were calculated (Kleiber, 1961). Total nitrogen excretion was assumed to be about $15 \%$ higher than ammonia-nitrogen excretion rates (Kaushik, 1980) and a mole-to-mole ratio of nitrogen excretion to oxygen uptake (NQ) was also calculated. From such data on RQ and NQ, the non-protein respiratory quoteints ( $\mathrm{npRQ}$ ) were calculated. Based on the assumption that total protein catabolism would lead to an NQ of 0.33 in ammoniotelic teleosts (Kutty, 1978) and on the basis of data on $n p R Q$, relative proportions of the metabolic utilization of protein, carbohydrates and fats were calculated.

\section{Study of glucose metabolism and its hormonal control}

At the end of the growth trial, blood samples were drawn from ten fish belonging to each batch, centrifuged, and glucose was determined in plasma using a glucose analyzer (Beckman). Of the five experimental groups, three groups 
(RS, ECS, and EWS) were selected (1) to study the postprandial glycemic response and (2) to study the metabolic utilization of glucose by the whole animal and by specific tissues like the muscle and liver. One hour after a meal, ten fish from each of the three groups were given an acute single intravenous (caudal vein) injection of radiolabelled $\left({ }^{3} \mathrm{H}\right.$ )-2-deoxyglucose (an analog of glucose) in saline ( $185 \mathrm{kBq} / 100 \mathrm{~g}$ body weight). Five of these fish were also given an intraperitoneal injection of bovine insulin (9.7 IU/100 g body weight); the five other fish received a sham saline injection. All fish were individually marked (dermojet) and kept isolated in individual containers with flowing water and sufficient oxygenation. At 1, 3 and $6 \mathrm{~h}$ after this treatment, $300 \mu \mathrm{l}$ of blood was sampled. Blood was treated with $\mathrm{H}_{2} \mathrm{O}_{2}$ and radioactivity was measured in a scintillation counter (Betamatic, Kontron). Blood glucose was also measured in an aliquot sample (Beckman glucose analyzer). Six hours after injection, muscle and liver samples were removed from all fish and frozen immediately. The results on tissue glucose metabolism will not be dealt with in this paper.

\section{Analytical methods}

Tissue and fecal samples were freeze-dried before analyses. Proximate composition of the diets, feces and carcasses were made following the usual procedures: dry matter $\left(110^{\circ} \mathrm{C}\right.$ for $\left.24 \mathrm{~h}\right)$, protein (Kjeldahl $(\mathrm{N} \times 6.25)$ after acid digestion, fat (after chloroform: methanol extraction), gross energy (Gallenkamp adiabatic bomb calorimeter), and chromic oxide using a semi-automated procedure (Mathieson, 1970) after perchloric acid digestion (Bolin et al., 1952). Statistical analyses were performed using the SAS package (SAS Inst. Inc., North Carolina, U.S.A. ).

\section{RESULTS AND DISCUSSION}

\section{Digestibility of protein and energy}

The digestibility coefficients of the experimental diets are reported in Table 2. As can be expected, the dry matter digestibility was lower in diet RS (raw starch) than in the other diets. Consequently, despite its higher fat content, the availability of dietary energy was only $64 \%$ in the diet RS (Table 2), whereas the digestibility of energy was about $85 \%$ in the other diets. These results are in accordance with previous findings (Kaushik and Oliva-Teles, 1985) on the improvement of $\mathrm{DE}$ by the inclusion of treated starch material in trout diets. Protein digestibility was high (above $90 \%$ ), confirming the good quality of the fishmeal used, and it was little affected by dietary carbohydrates. 
TABLE 2

Proximate composition and apparent digestibility coefficients (ADC) of the test diets $(\%)^{1}$

\begin{tabular}{lcrrrr}
\hline & RS & ECS & EC & EWS & EW \\
\hline Proximate composition & & & & & \\
$\quad$ Protein (\% DM) & 36.1 & 40.1 & 41.8 & 40.9 & 42.7 \\
Fat (\% DM) & 16.8 & 8.9 & 9.4 & 9.4 & 8.7 \\
Energy (kJ/g DM) & 22.0 & 20.5 & 20.9 & 20.6 & 20.5 \\
& & & & & \\
ADC values (\%) & & & & & $78.6^{\mathrm{b}}$ \\
$\quad$ Dry matter & $55.1^{\mathrm{a}}$ & $80.2^{\mathrm{b}}$ & $79.6^{\mathrm{b}}$ & $74.7^{\mathrm{b}}$ \\
Protein & $89.7^{\mathrm{a}}$ & $92.5^{\mathrm{a}}$ & $91.7^{\mathrm{a}}$ & $90.9^{\mathrm{a}}$ & $91.7^{\mathrm{a}}$ \\
Energy & $64.0^{\mathrm{a}}$ & $85.8^{\mathrm{b}}$ & $86.2^{\mathrm{b}}$ & $81.7^{\mathrm{b}}$ & $85.2^{\mathrm{b}}$ \\
\hline
\end{tabular}

${ }^{1}$ Figures in a row with different superscripts are significantly different from each other $(P<0.05)$.

\section{TABLE 3}

Nutrient intake ( $\mathrm{g}$ or $\mathrm{kJ} / \mathrm{kg}$ per day), growth performance, and nutrient utilization efficiencies in rainbow trout fed different experimental diets over 18 weeks at a water temperature of $18^{\circ} \mathrm{C}^{1}$

\begin{tabular}{lcccrr}
\hline & RS & ECS & EC & EWS & EW \\
\hline Nutrient intake & & & & & \\
Dry matter & $15.2^{\mathrm{a}}$ & $14.4^{\mathrm{a}}$ & $13.9^{\mathrm{a}}$ & $14.3^{\mathrm{a}}$ & $13.6^{\mathrm{a}}$ \\
Protein & $5.5^{\mathrm{a}}$ & $5.7^{\mathrm{a}}$ & $5.8^{\mathrm{a}}$ & $5.9^{\mathrm{a}}$ & $5.8^{\mathrm{a}}$ \\
Digestible energy & $204.3^{\mathrm{a}}$ & $255.7^{\mathrm{b}}$ & $247.2^{\mathrm{b}}$ & $242.5^{\mathrm{b}}$ & $249.0^{\mathrm{b}}$ \\
& & & & & \\
Growth performance & & & & & \\
Initial wt. (g) & $28.2^{\mathrm{a}}$ & $28.5^{\mathrm{a}}$ & $28.3^{\mathrm{a}}$ & $27.9^{\mathrm{a}}$ & $28.5^{\mathrm{a}}$ \\
Final wt. (g) & $115.1^{\mathrm{a}}$ & $122.1^{\mathrm{bc}}$ & $130.5^{\mathrm{c}}$ & $126.7^{\mathrm{ab}}$ & $110.8^{\mathrm{a}}$ \\
SGR (\%) & $1.41^{\mathrm{ab}}$ & $1.50^{\mathrm{bc}}$ & $1.53^{\mathrm{c}}$ & $1.48^{\mathrm{bc}}$ & $1.33^{\mathrm{a}}$ \\
FGR & $1.26^{\mathrm{a}}$ & $1.14^{\mathrm{ab}}$ & $1.10^{\mathrm{ab}}$ & $1.14^{\mathrm{ab}}$ & $1.18^{\mathrm{ab}}$ \\
PER & $2.1^{\mathrm{a}}$ & $2.1^{\mathrm{a}}$ & $2.1^{\mathrm{a}}$ & $2.0^{\mathrm{a}}$ & $1.9^{\mathrm{a}}$ \\
Protein retention (\%) & $36.6^{\mathrm{a}}$ & $37.8^{\mathrm{a}}$ & $37.1^{\mathrm{a}}$ & $35.8^{\mathrm{a}}$ & $34.0^{\mathrm{a}}$ \\
Energy retention (\%) & $33.5^{\mathrm{ab}}$ & $37.8^{\mathrm{bc}}$ & $40.0^{\mathrm{c}}$ & $35.1^{\mathrm{ab}}$ & $33.3^{\mathrm{a}}$ \\
Fat retention (\%) & $64.9^{\mathrm{a}}$ & $106.0^{\mathrm{b}}$ & $131.5^{\mathrm{c}}$ & $119.0^{\mathrm{bc}}$ & $106.0^{\mathrm{b}}$ \\
\hline
\end{tabular}

${ }^{1}$ Figures in a row with different superscripts are significantly different from each other $(P<0.05)$.

\section{Nutrient intake and growth performance}

In Table 3 the results are given on nutrient intake, body weight gain and other growth parameters. The method of feeding utilized appears to have been very efficient in bringing about almost equal digestible protein (DP) and gross energy (GE) intakes in all five groups, despite voluntarily imposed differences in dry matter intakes. Contrarily, the DE intakes were lower in fish fed raw starch than in those fed other carbohydrates, mainly due to the poor digesti- 
bility value of this diet. The final body weights, specific growth rates (SGR), feed:gain ratios (FRG) and energy retention efficiencies (RE) were significantly higher in trout fed extruded corn starch (ECS) or extruded corn (EC) than in those fed raw starch (RS) or extruded wheat (EW). Protein efficiency ratios (PER) and protein retention efficiencies (apparent NPU), on the other hand, were not all affected by the dietary treatments. These results, while confirming previous findings (Kaushik and Oliva-Teles, 1985) that even in the presence of crude starch, inclusion of more of fat can lead to improved growth performance, also show that incorporation of high levels of carbohydrates does not adversely affect growth performance or the retention of major nutrients. These results are in contradiction to the findings of Hilton and Atkinson (1982) and Hilton et al. (1982) that growth performance is reduced with levels of digestible starch (glucose) above $14 \%$ in trout diets at water temperatures of 11 to $15^{\circ} \mathrm{C}$. As water temperature seems to have some effect on hepatic glycogen mobilization (Hilton, 1982), more insight on the effect of water temperature on carbohydrate utilization is required.

\section{Body composition}

The hepatosomatic index (HSI = liver body weight ratio) was lowest in those fish fed diet EW (1.5) and highest (2.1) in fish fed ECS. These values are higher than those found by Hilton (1982) or Buddington and Hilton (1987) in trout fed between 14 to $24 \%$ glucose. The viscera to body weight ratio (VI) was, however, lower than that found by Buddington and Hilton (1987) and was not much affected by the dietary treatments ( 7.7 to $9.5 \%$ ). The dressed percentage (DP) varied between 85 and $88 \%$. In all the batches of fish fed the different experimental diets, the final body composition at the end of 18 weeks differed significantly from that of the initial carcass composition (Table 4). Protein content decreased and fat content increased. After 18 weeks, the fat contents of trout fed raw starch (RS) or extruded wheat (EW) were higher than in the other groups. In terms of fat deposition as percentage of fat intake, the results show that in these latter groups (EC, ECS and EWS) considerable lipogenesis occurred (Table 3).

\section{Nitrogen and energy balance studies}

On the basis of protein digestibility data, postprandial ammonia nitrogen excretion rates and carcass composition, nitrogen budgets for each diet could be established (Table 5). Reasonably good concordance was seen between retention values based on carcass composition and those based on balance data, given that ammonia-N excretion does not fully account for all nitrogenous metabolic wastes in salmonids (Kaushik, 1980). In terms of energy balance, SDA (specific dynamic action: estimated from differences in oxygen uptake 


\section{TABLE 4}

Body composition of fish and plasma glucose levels in trout fed different carbohydrate-rich diets over 18 weeks $^{1}$

\begin{tabular}{lcccccc}
\hline & Initial & RS & ECS & EC & EWS & EW \\
\hline Protein (\% DM) & $68.7^{\mathrm{a}}$ & $54.6^{\mathrm{c}}$ & $57.4^{\mathrm{bc}}$ & $56.1^{\mathrm{c}}$ & $56.0^{\mathrm{c}}$ & $59.7^{\mathrm{b}}$ \\
Fat (\% DM) & $11.1^{\mathrm{a}}$ & $36.0^{\mathrm{c}}$ & $33.9^{\mathrm{b}}$ & $36.4^{\mathrm{c}}$ & $34.4^{\mathrm{b}}$ & $30.2^{\mathrm{b}}$ \\
Energy (kJ/g DM) & $20.1^{\mathrm{a}}$ & $26.7^{\mathrm{b}}$ & $26.6^{\mathrm{b}}$ & $27.1^{\mathrm{b}}$ & $26.4^{\mathrm{b}}$ & $25.3^{\mathrm{b}}$ \\
& & & & & & \\
$\mathrm{HSI}^{2}(\%)$ & $1.0^{\mathrm{a}}$ & $1.7^{\mathrm{b}}$ & $2.1^{\mathrm{c}}$ & $1.8^{\mathrm{b}}$ & $1.8^{\mathrm{b}}$ & $1.5^{\mathrm{b}}$ \\
$\mathrm{VI}^{\mathrm{a}}(\%)$ & $6.2^{\mathrm{a}}$ & $9.5^{\mathrm{c}}$ & $7.7^{\mathrm{b}}$ & $7.9^{\mathrm{b}}$ & $7.8^{\mathrm{b}}$ & $8.5^{\mathrm{bc}}$ \\
$\mathrm{DP}^{4}(\%)$ & $90.2^{\mathrm{a}}$ & $85.7^{\mathrm{b}}$ & $94.8^{\mathrm{b}}$ & $87.6^{\mathrm{b}}$ & $86.2^{\mathrm{b}}$ & $85.7^{\mathrm{b}}$ \\
Plasma glucuse (mg/100 ml) & - & $65.3^{\mathrm{a}}$ & $80.0^{\mathrm{b}}$ & $59.5^{\mathrm{a}}$ & $60.6^{\mathrm{a}}$ & $70.8^{\mathrm{a}}$ \\
\hline
\end{tabular}

${ }^{1}$ Figures in a row with different superscripts are significantly different from each other $(P<0.05)$. ${ }^{2} \mathrm{HSI}=$ liver to body weight ratio.

${ }^{3} \mathrm{VI}=$ viscera to body weight ratio.

${ }^{4} \mathrm{DP}=$ dressed percentage.

\section{TABIE 5}

Nitrogen and energy balance in rainbow trout fed different carbohydrate-rich diets (data as $\%$ of nitrogen or energy intakes) ${ }^{1}$

\begin{tabular}{|c|c|c|c|c|c|}
\hline & RS & ECS & EC & EWS & EW \\
\hline \multicolumn{6}{|l|}{ Nitrogen } \\
\hline Fecal losses & 11 & 8 & 8 & 9 & 8 \\
\hline Metabolic losses $^{2}$ & 51 & 42 & 42 & 46 & 47 \\
\hline \multicolumn{6}{|l|}{ Energy } \\
\hline $\mathrm{DE}$ & $64^{\mathrm{a}}$ & $86^{\mathrm{b}}$ & $86^{\mathrm{b}}$ & $82^{b}$ & $85^{b}$ \\
\hline $\mathrm{ME}^{3}$ & $57^{\mathrm{a}}$ & $81^{b}$ & $82^{\mathrm{b}}$ & $77^{\mathrm{b}}$ & $82^{b}$ \\
\hline $\mathrm{RE}$ & $35^{\mathrm{ab}}$ & $38^{\mathrm{b}}$ & $40^{b}$ & $35^{\mathrm{a}}$ & $32^{\mathrm{a}}$ \\
\hline SDA & $23^{\mathrm{a}}$ & $14^{\mathrm{b}}$ & $17^{\mathrm{b}}$ & $19^{b}$ & $17^{\mathrm{b}}$ \\
\hline
\end{tabular}

${ }^{1}$ Figures in a row with different superscripts are significantly different from each other $(P<0.05)$.

${ }^{2}$ Ammonia-nitrogen excretion.

${ }^{3}$ Metabolizable energy: calculated from measured ammonia- $\mathrm{N}$ excreted $\times 24.9 \mathrm{~kJ} / \mathrm{g}$.

data between fed and fasted fish) was higher in fish fed raw starch (23\% of gross energy intake) than in the other fish (14 to 19\%) (Table 5).

\section{Metabolic substrate utilization}

In Table 6 are presented the values on the metabolic rates, SDA, the RQ, $\mathrm{NQ}$ and the substrate utilization in fish fed the different diets. The fasting metabolic rates were higher in those fed extruded wheat (EW) or extruded 
TABLE 6

Oxygen uptake and $\mathrm{CO}_{2}$ excretion $\left(\mathrm{ml} \mathrm{kg}^{-1} \mathrm{~h}^{-1}\right), \mathrm{RQ}, \mathrm{NQ}$ in fed and fasted rainbow trout with a calculation of SDA in fed fish and the metabolic utilization of substrates in fasted fish ${ }^{1}$

\begin{tabular}{|c|c|c|c|c|c|}
\hline & $\mathrm{RS}$ & ECS & EC & EWS & EW \\
\hline \multicolumn{6}{|l|}{ Fasting fish } \\
\hline $\mathrm{O}_{2}$ uptake & 105 & 102 & 100 & 118 & 116 \\
\hline Metabolic rate $\left(\mathrm{kJ} \mathrm{kg}^{-1} \mathrm{~h}^{-1}\right)$ & $2.0^{\mathrm{a}}$ & $2.0^{\mathrm{a}}$ & $1.9^{\mathrm{a}}$ & $2.3^{\mathrm{b}}$ & $2.3^{b}$ \\
\hline $\mathrm{CO}_{2}$ excreted & 93 & 94 & 90 & 106 & 102 \\
\hline $\mathrm{RQ}^{2}$ & $0.89^{\mathrm{a}}$ & $0.93^{\mathrm{b}}$ & $0.90^{\mathrm{a}}$ & $0.90^{\mathrm{a}}$ & $0.87^{\mathrm{a}}$ \\
\hline$N^{3}$ & $0.04^{a}$ & $0.03^{\mathrm{a}}$ & $0.08^{\mathrm{b}}$ & $0.06^{\mathrm{ab}}$ & $0.05^{a}$ \\
\hline$n p R Q^{4}$ & $0.91^{\mathrm{a}}$ & $0.94^{\mathrm{b}}$ & $0.94^{\mathrm{b}}$ & $0.93^{\mathrm{ab}}$ & $0.89^{\mathrm{a}}$ \\
\hline \multicolumn{6}{|l|}{ Substrate utilization } \\
\hline Protein & $14^{\mathrm{b}}$ & $10^{a}$ & $24^{c}$ & $18^{\mathrm{bc}}$ & $15^{\mathrm{b}}$ \\
\hline Carbohydrates & $60^{\mathrm{a}}$ & $73^{\mathrm{b}}$ & $61^{a}$ & $63^{a}$ & $55^{\mathrm{a}}$ \\
\hline Fats & $26^{\mathrm{b}}$ & $17^{\mathrm{a}}$ & $15^{\mathrm{a}}$ & $19^{a}$ & $30^{\mathrm{b}}$ \\
\hline \multicolumn{6}{|l|}{ Fed fish ( $8 \mathrm{~h}$ postprandial) } \\
\hline $\mathrm{O}_{2}$ uptake & 201 & 165 & 179 & 198 & 194 \\
\hline $\mathrm{CO}_{2}$ excreted & 178 & 144 & 154 & 172 & 166 \\
\hline $\mathrm{RQ}$ & $0.89^{b}$ & $0.87 \mathrm{~b}$ & $0.83^{\mathrm{a}}$ & $0.87^{b}$ & $0.86^{\mathrm{ab}}$ \\
\hline $\mathrm{SDA}^{5}\left(\mathrm{~kJ} \mathrm{~kg}^{-1} \mathrm{~h}^{-1}\right)$ & $1.86^{c}$ & $1.22^{\mathrm{a}}$ & $1.52^{\mathrm{b}}$ & $1.55^{\mathrm{b}}$ & $1.50^{\mathrm{b}}$ \\
\hline
\end{tabular}

${ }^{1}$ Figures in a row with different superscripts are significantly different from each other $(P<0.05)$.

${ }^{2} \mathrm{RQ}=$ respiratory quotient.

${ }^{3} \mathrm{NQ}=$ nitrogen quotient.

${ }^{4} \mathrm{npRQ}=$ non-protein respiratory quotient.

${ }^{5} \mathrm{SDA}=$ specific dynamic action.

wheat starch (EWS) than in the other groups. The SDA, on the other hand, was highest in trout fed the crude starch/high fat diet (diet RS) and lowest in those fed the diet containing extruded corn starch (ECS). Interestingly, in fish fasted for 5 days the carbohydrates served as the major energy substrate in the latter group (ECS) while fats were utilized more in the former group (RS). In contrast to body lipid deposition (Table 3) which was high in group EC, ECS and EWS, in fasting fish of the same group, fat mobilization as measured from metabolic data was low (15 to $19 \%$ ). To our knowledge, no comparative data based on such metabolic parameters are yet available in fish. Respirometric data along with data on nitrogen catabolism appear to provide useful information, and such an approach requires more attention.

\section{Postprandial glycemia and its control by insulin}

At the end of the growth trial, the plasma glucose levels measured after a 24$h$ fast were higher in the trout fed ECS and no significant difference was found 


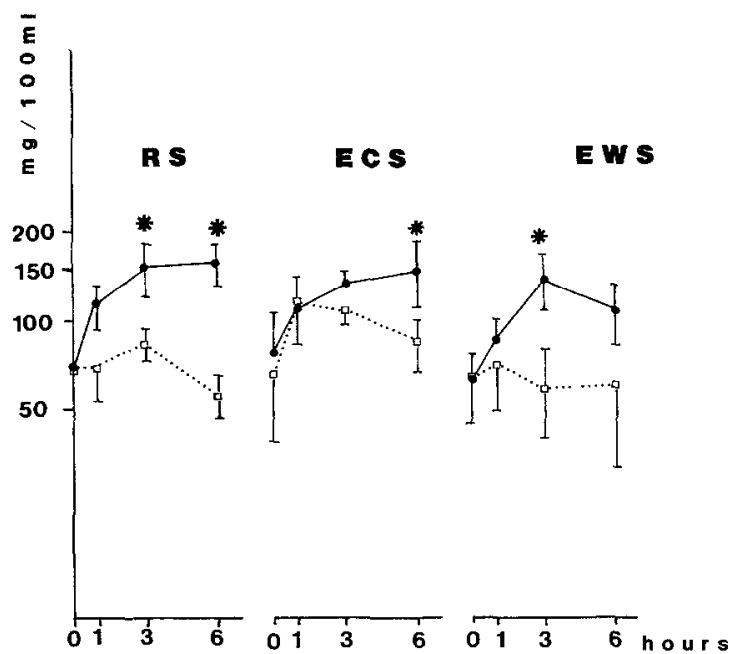

Fig. 1. Changes in plasma glucose levels after an injection of either saline $(\bullet)$ or of $9.7 \mathrm{IU} / 100 \mathrm{~g}$ BW of bovine insulin ( $\square$ ) an hour after the last meal. Means and standard deviations are given. The asterisks indicate that the levels were significantly different from the initial levels.

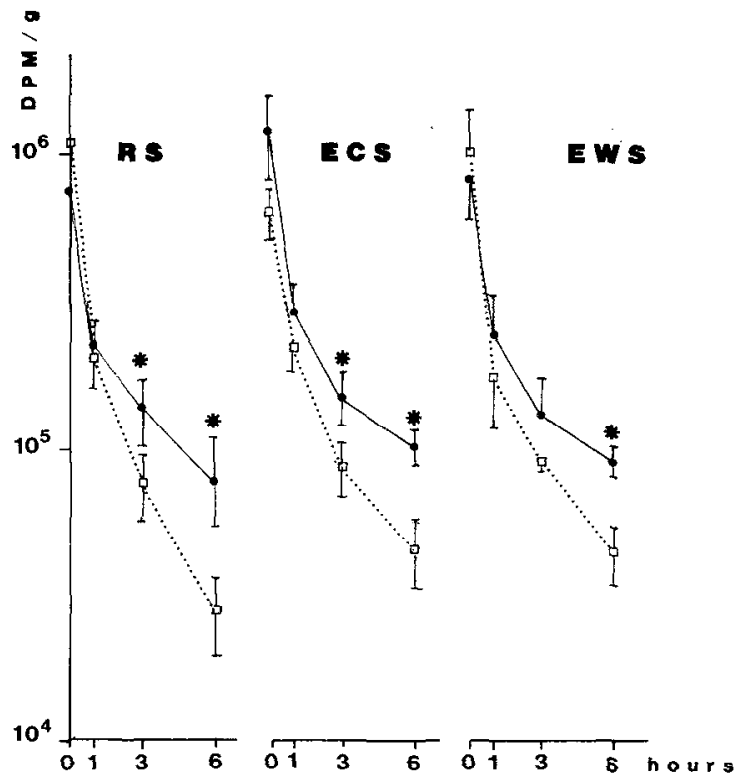

Fig. 2. Changes in radioactivity in plasma after a single intravenous injection of $\left({ }^{3} \mathrm{H}\right)$-deoxyglucose, followed by an injection of either saline $(\bullet)$ or of $9.7 \mathrm{IU} / 100 \mathrm{~g} \mathrm{BW}$ of bovine insulin $(\square)$ an hour after the last meal. Means and standard deviations are given. The asterisks indicate that the levels were significantly different from the initial levels. 
between the other four groups (Table 4). These levels are in accordance with earlier data of Bergot (1979). The changes in plasma glucose profile and the effect of insulin in the three groups which were selected for further feeding (RS, ECS and EWS) are presented in Fig. 1. Between 1 and $6 \mathrm{~h}$ after injection, the peak levels reached in the three groups were not different. In those fish receiving an injection of bovine insulin, the decline in plasma glucose followed a more or less similar pattern. These results are similar to those observed by Furuichi and Yone (1982) in other fish such as the yellowtail (Seriola quinqueradiata) or the red sea bream (Chrysophrys major). Likewise, in terms of radioactivity of the injected 2-deoxyglucose, the patterns of decline were not different in the three groups (Fig. 2). Insulin injection ellicited the same kind of response in the three groups, suggesting that long-term feeding with either raw or digestible starches does not confer on trout any specific adaptive regulatory control of plasma glucose levels. Buddington and Hilton (1987) have similarly shown that there is a lack of adaptation of the digestive system to long-term utilization of high levels of carbohydrates.

\section{REFERENCES}

Bergot, F., 1979. Effects of dietary carbohydrates and of their mode of distribution on glycaemia in rainbow trout (Salmo gairdneri Richardson). Comp. Biochem. Physiol., 64A: 543-547.

Bergot, F. and Breque, J., 1983. Digestibility of starch by rainbow trout: effects of the physical state of starch and of the intake level. Aquaculture, 22: 81-96.

Bolin, D.W., King, R.P. and Klosterman, W.W., 1952. A simplified method for the determination of chromic oxide $\left(\mathrm{Cr}_{2} \mathrm{O}_{3}\right)$ when used as an inert substance. Science, 16: 634-635.

Buddington, R.K. and Hilton, J.W., 1987. Intestinal adaptations of rainbow trout to changes in dietary carbohydrate. Am. J. Physiol., 253 (Gastrointest. Liver Physiol., 16): G489-G496.

Cho, C.Y. and Kaushik, S.J., 1985. Effects of protein intake on metabolizable and net energy values of fish diets. In: C.B. Cowey, A.M. Mackie and J.G. Bell (Editors), Nutrition and Feeding of Fish. Academic Press, London, pp. 95-117.

Choubert, G., De la Noue, J. and Luquet, P., 1982. Digestibility in fish: an improved device for the automatic collection of feces. Aquaculture, 29: 185-189.

Furuichi, M. and Yone, Y., 1981. Change of blood sugar and plasma insulin levels of fishes in glucose tolerance test. Bull. Jpn. Soc. Sci. Fish., 47: 761-764.

Furuichi, M. and Yone, Y., 1982. Effect of insulin on blood sugar levels of fishes. Bull. Jpn. Soc. Sci. Fish., 48: 1289-1291.

Hilton, J.W., 1982. The effect of pre-feeding diet and water temperature on liver glycogen and liver weight in rainbow trout, Salmo gairdneri, during fasting. J. Fish Biol,, 20: 69-78.

Hilton, J.W. and Atkinson, J.L., 1982. Responses of rainbow trout (Salmo gairdneri) to increased levels of available carbohydrate in practical trout diets. Br. J. Nutr., 47: 597-607.

Hilton, J.W., Atkinson, J.L. and Slinger, S.J., 1982. Maximum tolerance level, digestion and metabolism of D-glucose (cerelose) in rainbow trout (Salmo gairdneri) reared on a practical diet. Can. J. Fish. Aquat. Sci., 39: 1229-1234.

Inaba, D., Ogino, C., Takamatsu, C., Ueda, T. and Kurokawa, K., 1963. Digestibility of dietary components in fishes. 2. Digestibility of dietary protein and starch in rainbow trout. Bull. Jpn. Soc. Sci. Fish., 29: 242-244. 
Kaushik, S.J. 1980. Influence of nutritional status on the daily patterns of nitrogen excretion in carp (Cyprinus carpio L.) and rainbow trout (Salmo gairdneri). Reprod. Nutr. Dév., 20: 17511765 .

Kaushik, S.J. and Oliva-Teles, A., 1985. Effects of digestible energy on nitrogen and energy balance in rainbow trout. Aquaculture, 50: 89-101.

Kleiber, M., 1961. The Fire of Life. Wiley, New York, NY, 454 pp.

Kutty, M.N. 1978. Ammonia quotient in sockeye salmon (Oncorhynchus nerka). J. Fish. Res. Board Can., 35: 1003-1005.

Luquet, P. and Bergot, F., 1976. Evaluation de divers traitements technologiques des céréales. VII. Utilisation de maïs pressé, floconné, expansé et extrudé dans l'alimentation de la truite arc-enciel. Ann. Zootech., 25: 63-69.

Mathieson, J., 1970. The automated estimation of chromic oxide. Proc. Nutr. Soc., 29: 30A-31A.

Palmer, T.N. and Ryman, B.E., 1972. Studies on oral glucose intolerance in fish. J. Fish Biol., 4: 311-319.

Singh, R.P. and Nose, T., 1967. Digestibility of carbohydrates in young rainbow trout. Bull. Freshwater Fish. Res. Lab. Tokyo, 17: 21-25.

Watanabe, T., Takeuchi, T. and Ogino, C., 1979. Studies on the sparing effect of lipids on dietary protein in rainbow trout (Salmo gairdneri). In: K. Tiews and J.E. Halver (Editors), Finfish Nutrition and Fishfeed 'Technology, Vol. I. Heenemann, Berlin, pp. 113-125.

Watanabe, T., Takeuchi, T., Satoh, S., Ida, T. and Yaguchi, M., 1987. Development of low proteinhigh energy diets for practical carp culture with special reference to reduction of total nitrogen excretion. Nippon Suisan Gakkaishi, 53: 1413-1423. 